\title{
EFFECT OF AGE AND SEASONAL VARIATIONS ON LEACHATE CHARACTERISTICS OF MUNICIPAL SOLID WASTE LANDFILL
}

\author{
Barjinder Bhalla ${ }^{1}$, M.S. Saini ${ }^{2}$, M.K. Jha ${ }^{3}$ \\ ${ }^{1}$ Scientist C, Pushpa Gujral Science City, Kapurthala- 144601, Punjab, India \\ ${ }^{2}$ Director, Guru Nanak Dev Engineering College, Ludhiana-141006, Punjab, India \\ ${ }^{3}$ Professor, Department of Chemical Engineering, Dr.B.R.Ambedkar National Institute of Technology, \\ Jalandhar-144011, Punjab, India. \\ barjinderbhalla@hotmail.com
}

\begin{abstract}
The paper discusses the effect of age and seasonal variations on leachate characteristics of leachate generated from municipal solid waste (MSW) landfill site of Ludhiana City, Punjab (India). Leachate samples were collected and analyzed for various physicochemical parameters to estimate its pollution potential. MSW landfill site is non-engineered low lying open dump. It has neither any bottom liner nor any leachate collection and treatment system. Therefore, all the leachate generated finds its paths into the surrounding environment. The landfill site is not equipped with any leachate collectors. Leachate samples were collected from the base of solid waste heaps where the leachate was drained out by gravity. It has been found that leachate contains high concentrations of organic and inorganic constituents beyond the permissible limits. While, heavy metals concentration was in trace amount as the waste is domestic in nature. The data presented in this study indicated that with the passage of time and with seasonal variations particularly during rainy season values of various parameters increased, reason being with time the solid waste material degraded and the waste constituents percolated down along with rainwater. Thus, the age and seasonal variations has a significant effect on leachate composition. Indiscriminate dumping of MSW without proper solid waste management practices should be stopped or some remedial measures were required to be adopted to prevent contamination.
\end{abstract}

Index Terms: Municipal solid waste, Landfill, Leachate, Organic and Inorganic constituents

\section{INTRODUCTION}

India, the world's second highest populated country with population exceeding a billion and one of the fastest urbanizing countries, is a land of physical, climatic, geographic, ecological, social, cultural and linguistic diversity. India currently is facing a municipal solid waste dilemma, for which all elements of the society are responsible. The community sensitization and public awareness is low. There is no system of segregation of organic, inorganic and recyclable wastes at household level. There is an adequate legal framework existing in the country to address MSWM. What is lacking is its implementation. In spite of a stringent legislation in place, open dumping is the most wide spread form of waste disposal. The possible reasons for poor implementation could be a combination of social, technical, institutional and financial issues. Public awareness, political will and public participation are essential for the successful implementation of the legal provisions and to have an integrated approach towards sustainable management of municipal solid wastes in the country. Management of Municipal Solid Wastes (MSW) continues to remain one of the most neglected areas of urban development in India. With the rapid industrialization and population growth, the status of our environment is degrading day by day. As the limits of urbanization are extending to far flying areas in India, the problem of solid waste management is causing a great concern to our environment. MSW generation, in terms of $\mathrm{kg} / \mathrm{capita} /$ day, has shown a positive correlation with economic development at world scale. Due to rapid industrial growth and migration of people from villages to cities, the urban population is increasing rapidly. Waste generation has been observed to increase annually in proportion to the rise in population and urbanization. The per capita generation of MSW has also increased tremendously with improved life style and social status of the populations in urban centers [1]. As more land is needed for the ultimate disposal of these solid wastes, issues related to disposal have become highly challenging [2]. Seeing the scenario of increase in generation, improper utilization and disposal of waste in the country, the Ministry of Environment and Forest (MoEF) has implemented Municipal Solid Waste (Management and Handling) Rules, 2000 [3], which states that Municipal Solid Waste (MSW) is commercial and residential wastes generated in a municipal or notified areas in either solid or semi-solid form, excluding industrial hazardous wastes but including treated biomedical wastes. These solid wastes are generally disposed off in a low lying area called sanitary landfill area by the municipal authorities. These rules have specified many 
compliance for the management of solid waste for the State Committee and Pollution Board, which includes proper segregation of solid waste into biodegradable waste, recyclable and others i.e., non-recyclable wastes are stored in colored bins at the source of generation and properly treated, recycled and disposed to landfill areas.

The quantity of municipal solid waste in developing countries has been consistently rising over the years [4]. Today more than 45 million tones/year of solid waste is generated from the urban centres of India which are collected inefficiently, transported inadequately and disposed unscientifically [5]. The generation is expected to rise to 125 million tonnes/year by the year 2025 [6]. According to Ministry of Urban Affairs, Govt. of India estimate, India is generating approximately 100,000 metric tones of solid waste everyday of which $90 \%$ is dumped in the open place [7]. In Delhi, the capital of India alone, more than 5000 tonnes of MSW is generated everyday and is expected to rise to 12750 tonnes per day by 2015 [8]. The MSW generated per day in India's other major cities are Mumbai-6050 tonnes, Kolkata -3500 tonnes, Chennai-2500 tonnes, Bangalore-2000 tonnes, Hyderabad-1800 to 2000 tonnes, Lucknow-1500 tonnes and Ahmedabad-1280 tonnes [7]. The municipal solid waste composition varies from place to place and also bears a rather consistent correlation with the average standard of living [9].

Generally in India, MSW is disposed of in low-lying areas without taking proper precautions or operational controls. Therefore, municipal solid waste management (MSWM) is one of the major environmental problems of Indian megacities. MSW management encompasses planning, engineering, organization, administration, financial and legal aspects of activities associated with generation, storage, collection, transport, processing and disposal in an environmentally compatible manner adopting principles of economy, aesthetics and energy conservation [10]. The management of MSW is going through a critical phase, due to the unavailability of suitable facilities to treat and dispose of the larger amounts of MSW generated daily in metropolitan cities. The MSW amount is expected to increase significantly in the near future as India strives to attain an industrialized nation status by the year $2020[11,12,13]$. The management of MSW requires proper infrastructure, maintenance and upgrade for all activities. This becomes increasingly expensive and complex due to the continuous and unplanned growth of urban centres. The difficulties in providing the desired level of public service in the urban centres are often attributed to the poor financial status of the managing municipal corporations $(8,14,15]$.

Inefficient management and disposal of MSW is an obvious cause for degradation of environment in the developing countries. Ecological impacts such as land degradation, water and air pollution are related with improper management of municipal solid waste [16]. In Asian developing countries, most of the municipal solid waste is dumped on land in more or less uncontrolled manner. Lack of sufficient awareness at the grassroots level of the waste generators add to the problem of littering. As a result there is a serious threat to public health due to environmental pollution. Unscientific disposal causes an adverse impact on all components of the environment and human health $[17,18,19,20,21,22]$.

\subsection{LEACHATE GENERATION AND} CHARACTERIZATION

One of the major pollution problems caused by the MSW landfill is landfill leachate, which is generated as a consequence of precipitation, surface run-off and infiltration or intrusion of groundwater percolating through a landfill, biochemical processes and the inherent water content of wastes themselves. Leachate is the liquid residue resulting from the various chemical, physical and biological processes taking place within the landfill. Landfill leachate is generated by excess rainwater percolating through the waste layers in a landfill. A combination of physical, chemical and microbial processes in the waste transfer pollutants from the waste material to the percolating water [23]. After a landfill site is closed, a landfill will continue to produce contaminated leachate and this process could last for 30-50 years. Generally, leachate may contain large amounts of organic matter (biodegradable, but also refractory to biodegradation), as well as ammonia-nitrogen, heavy metals, chlorinated organic and inorganic salts, which are a great threat to the surrounding soil, groundwater and even surface water [24,25]. The compositions of leachate can be divided into four parts of pollutants. Organic matter such as: COD (chemical oxygen demand) and TOC (total organic carbon); specific organic compounds, inorganic compounds and heavy metals [26]. However, the organic content of leachates is often measured through analyzing sum of parameters such as COD, BOD (biochemical oxygen demand) and TOC and dissolved organic carbon.

The composition of landfill leachate, the amount generated and the extraction of potential pollutants from the waste depend upon several factors, including solid waste composition, degree of compaction, absorptive capacity of the waste and waste age, seasonal weather variations, levels of precipitation, Landfill temperature, size, hydrogeological conditions in the vicinity of the landfill site, engineering and operational factors of the landfill, $\mathrm{pH}$, landfill chemical and biological activities [27,28,29,30]. A simplified water balancing equation takes all of these factors into account and allows designers to predict an amount of leachate that will be produced by the landfill.

Canziani and Cossu [31] created this equation in particular:

$$
\mathrm{L}=\mathrm{P}-\mathrm{R}-\mathrm{DU}-\mathrm{ET}-\mathrm{Duw}
$$


$\mathrm{L}=$ leachate production

$\mathrm{P}=$ precipitation

$\mathrm{R}=$ surface run-off

Us $=$ change in soil moisture

$\mathrm{ET}=$ actual evaporative losses from the bare-soil/ evapotranspiration losses from a vegetated surface

$\mathrm{Uw}=$ change in the moisture content of the refuse components

The production of leachate also varies widely through the successive aerobic, acetogenic, methanogenic and stabilization stages. The degradation process of the waste in a landfill passes through different phases. The first phase which is normally short is characterized by the aerobic degradation of organic matter. When the oxygen is depleted, the degradation continues anaerobically. The anaerobic degradation process consists of two major fermentation phases, the acidogenic phase generating "young", biodegradable leachate and the methanogenic phase, generating "old", stabilised leachate [32]. During fermentation organic molecules are broken down into simpler substances in an energy yielding process. Some physico-chemical characteristics are typical for each phase whereas other parameters are not specifically phase dependant.

"Young" leachate from the early acidogenic phase contains large amounts of readily biodegradable organic matter. The complex organic compounds are fermented anaerobically, yielding mainly soluble organic acids such as free volatile fatty acids (VFAs), amino acids, other low molecular weight compounds and gases like $\mathrm{H}_{2}$ and $\mathrm{CO}_{2}$ [33]. The concentration of VFAs can be quite significant, representing $95 \%$ of the total organic carbon (TOC), leading to low pH (around 5). Typical chemical oxygen demand (COD) values are 3000-60000 mg/l [34]. High ratio $\mathrm{BOD}_{5} / \mathrm{COD}$ values of $0.5-0.7$ indicate large amounts of biodegradable organic matter [35,36]. During this phase the metals are more soluble because of lower $\mathrm{pH}$ and the bonding with the VFAs, leading to relative high concentrations of $\mathrm{Fe}, \mathrm{Mn}, \mathrm{Ni}$ and $\mathrm{Zn}$ [33].

"Old" leachate from the methanogenic phase is partially characterized by the lower concentration of VFAs [35]. This is due to their conversion into $\mathrm{CH}_{4}$ and $\mathrm{CO}_{2}$ as gaseous end products during this second fermentation period. As the content of VFAs and other readily biodegradable organic compounds in the leachate decreases, the organic matter in the leachate becomes dominated by refractory compounds, such as humic like compounds and fulvic acid like substances [33]. Thus a low ratio $\mathrm{BOD}_{5} / \mathrm{COD}$, most often close to 0.1 , is a characteristic value for stabilised leachates [36]. The humic substances give a dark colour to stabilised leachates. The decrease of VFAs results in an increase in $\mathrm{pH}$. A characteristic $\mathrm{pH}$ value for stabilised leachates is around 8 [36]. The concentration of metal ions is in general low due to the decreasing solubility of many metal ions with increasing $\mathrm{pH}$. However, lead is an exception, since it forms very stable complexes with the humic acids [33]. Besides the effect of the shifting $\mathrm{pH}$ on metal-ions, there is the reduction of sulphate to sulphide during this phase, which increases the precipitation of metals ions.

In general, the strength of leachate decreases with time due to biological breakdown of organic compounds and precipitation of soluble elements such as heavy metals. Due to its biodegradable nature, the organic compounds decrease more rapidly than the inorganic compounds with increasing age of leachate production. Therefore the ratio of total volatile solids to total fixed solids (VS/FS) decreases with the age of the landfill [35].

Three main groups of landfills are classified as young (less than five years), intermediate (5-10 years), and old or stabilized (more than 10 years). Table 1 summarizes the typical characteristics of leachate according to age of landfill [24,37]. The typical chemical concentrations in young and old landfill leachate comparing with sewage and groundwater are also shown in Table 2 [38].

Table- 1: Characteristics of leach ate at different ages of landfill

\begin{tabular}{|l|c|c|c|}
\hline \multicolumn{1}{|c|}{ Parameter } & Young & Intermediate & Old \\
\hline Age (years) & $<5$ & $5-10$ & $>10$ \\
\hline $\mathrm{pH}$ & 6.5 & $6.5-7.5$ & $>7.5$ \\
\hline COD (mg/l) & $>10,000$ & $4,000-10,000$ & $<4,000$ \\
\hline BOD 5 /COD & $>0.3$ & $0.1-0.3$ & $<0.1$ \\
\hline $\begin{array}{l}\text { Organic } \\
\text { compounds }\end{array}$ & $\begin{array}{c}80 \% \text { volatile } \\
\text { fat acids } \\
\text { (VFA) }\end{array}$ & $\begin{array}{c}5-30 \% \text { VFA+ } \\
\text { humic and } \\
\text { fulvic acids }\end{array}$ & $\begin{array}{c}\text { Humic and } \\
\text { fulvic } \\
\text { acids }\end{array}$ \\
\hline $\begin{array}{l}\text { Heavy } \\
\text { metals }\end{array}$ & $\begin{array}{c}\text { Low-medium } \\
\text { Bidegradabi } \\
\text { lity }\end{array}$ & $\begin{array}{l}\text { Important } \\
\text { Low }\end{array}$ & Low \\
\hline
\end{tabular}


Table -2 : Typical concentrations in landfill leachate comparing with sewage and groundwater

\begin{tabular}{|l|c|c|c|c|}
\hline Parameters & $\begin{array}{c}\text { Young } \\
\text { leachate } \\
\text { concent } \\
\text { ration }\end{array}$ & $\begin{array}{c}\text { Old } \\
\text { leachate } \\
\text { concent } \\
\text { ration }\end{array}$ & $\begin{array}{c}\text { Typical } \\
\text { sewage } \\
\text { concentr } \\
\text { ation }\end{array}$ & $\begin{array}{c}\text { Typical } \\
\text { ground } \\
\text { water } \\
\text { conc. }\end{array}$ \\
\hline $\begin{array}{l}\mathrm{COD} \\
(\mathrm{mg} / \mathrm{l})\end{array}$ & $\begin{array}{c}20,000- \\
40,000\end{array}$ & $\begin{array}{c}500- \\
3,000\end{array}$ & 350 & 20 \\
\hline $\begin{array}{l}\mathrm{BOD}_{5} \\
(\mathrm{mg} / \mathrm{l})\end{array}$ & $\begin{array}{c}10,000- \\
20,000\end{array}$ & $50-100$ & 250 & 0 \\
\hline $\begin{array}{l}\mathrm{TOC} \\
(\mathrm{mg} / \mathrm{l})\end{array}$ & $9,000-$ & $100-$ & 100 & 5 \\
\hline $\begin{array}{l}\text { Volatile } \\
\text { fatty acids } \\
(\mathrm{mg} / \mathrm{l})\end{array}$ & 25,000 & 1,000 & & \\
\hline
\end{tabular}

Normally, young landfill leachate (the acid-phase landfill, $<5$ years) contain large amounts of biodegradable organic matter. More than $95 \%$ of the dissolved organic carbon (DOC) consists of volatile fatty acids, and little of high molecular weight compounds. In mature landfills (the methanogenicphase landfill), the organic fraction in the leachate becomes dominated by refractory compounds, and the DOC content consists of high molecular weight compounds $[39,40]$.

Table 3. Details of landfill site

\begin{tabular}{|c|c|c|c|}
\hline Location & $\begin{array}{c}\text { Land } \\
\text { area } \\
\text { (acres) }\end{array}$ & $\begin{array}{c}\text { Average } \\
\text { depth } \\
\text { (in ft.) }\end{array}$ & $\begin{array}{c}\text { Future } \\
\text { life } \\
\text { (years) }\end{array}$ \\
\hline Jamalpur landfill site & 25 & 8 to 10 & 25 \\
\hline
\end{tabular}

According to the study of Diamadopoulos, the concentration of the organic substances and the ratio of BOD to COD are generally higher during the active stage of decomposition and decrease gradually due to leachate stabilization [41].

In the present study, the experimental work is carried out to determine the effect of landfill age and seasonal variation on leachate characteristics of leachate generated from MSW landfill site of Ludhiana City, Punjab.

Leachate samples were collected and analyzed for various physico-chemical parameters to estimate its pollution potential. The effect of landfill age and seasonal variation on leachate composition was studied. This study aims to serve as a reference for the implementation of the most suitable technique for reducing the negative environmental effects of discharged leachate.

\subsection{STUDY LOCATION}

Ludhiana is the largest city in Punjab, both in terms of area and population lies between latitude $30^{\circ} 55^{\prime} \mathrm{N}$ and longitude $75^{0} 54^{\prime}$ E. The Municipal Corporation limit of city is spread over an area of $141 \mathrm{sq} . \mathrm{km}$. The population of the city within the Municipal Corporation area is estimated at 34,87,882 in 2011 [42]. The climate of Ludhiana is semi arid with maximum mean temperature reaching upto $42.8^{\circ} \mathrm{C}$ and minimum mean temperature is as below as $11.8^{0} \mathrm{C}$. Total rainfall during the year is $600-700 \mathrm{~cm} ; 70 \%$ of total rainfall occurs from July to September. The altitude varies from $230 \mathrm{~m}$ to $273 \mathrm{~m}$ from mean sea level [43]. Leachate sample for the present study was collected from Jamalpur landfilling site of Ludhiana City. (Table3). No cover of any description is placed over the spread waste to inhabit the ingress of surface water or to minimize litter blow and odours or to reduce the presence of vermin and insects. Rag pickers regularly set fire to waste to separate non-combustible materials for recovery. Since, there are no specific arrangements to prevent flow of water into and out of landfill site, the diffusion of contaminants released during degradation of landfill wastes, may proceed uninhibited. No proper compaction is done to compress the waste into the site.

\section{MATERIALS AND METHODS}

\subsection{Leachate Sampling and Analysis}

To determine the quality of leachate, integrated samples were collected from different landfill locations. Leachate sample was collected from landfill site on Tajpur Road at Jamalpur Village having 25 acres of low lying land area. This site is non-engineered low lying open dump. It has neither any bottom liner nor any leachate collection and treatment system. Therefore, all the leachate generated finds its paths into the surrounding environment. The landfill site is not equipped with any leachate collectors. Leachate samples were collected from the base of solid waste heaps where the leachate was drained out by gravity.

Leachate sampling was carried out in January 2012 during winter season in May, 2012 during summer season and in July 2012 during rainy season in Punjab. Leachate samples were collected from the same locations to determine the effect of age and seasonal variations on leachate characteristics of MSW landfill. Various physico-chemical parameters like viz pH, Total Solids (TS) Suspended Solids (TSS), Total Dissolved Solids (TDS), Turbidity, Hardness, Biological Oxygen Demand (BOD), Chemical Oxygen Demand (COD), Chloride $\left(\mathrm{Cl}^{-}\right)$, Nitrate $\left(\mathrm{NO}_{3}^{-}\right)$, Total Phosphorus (TP), Sulphate $\left(\mathrm{SO}_{4}{ }^{2-}\right)$ and heavy metals like Iron $(\mathrm{Fe})$, Lead $(\mathrm{Pb})$, Chromium (Cr), Cadmium (Cd), Copper $(\mathrm{Cu})$, Zinc $(\mathrm{Zn})$, Nickel (Ni) and Arsenic (As) were analyzed to determine pollution potential of leachate discharge from MSW landfill site to estimate its pollution potential. 


\subsection{Analytical Work}

Analytical methods were according to "Standard methods for examination of water and wastewater" specified by American Public Health Association [44]. The $\mathrm{pH}$ was measured by electronic $\mathrm{pH}$ meter $\left(4500-\mathrm{H}^{+} . \mathrm{B}\right.$ of Standard Methods). Total Solids (TS) was determined by properly shaken unfiltered sample and estimated by gravimetric method (2540.B of Standard Methods). Total Dissolved Solids (TDS) was determined by filtered sample through Whatman filter paper44 and estimated by gravimetry (2540.C: Standard Methods). Turbidity was measured by Nephelometer by using optical properties of light. (2130.B of Standard Methods). Chemical Oxygen Demand (COD) was determined by refluxion of sample followed by titration with Ferrous Ammonium Sulphate (FAS) was adopted (5220.C: Standard Methods). Biological Oxygen Demand (BOD) - Winkler's method was used for estimating initial and final DO in the sample and BOD was determined (5210-B of Standard methods). Argentometric volumetric titration method in the presence of Potassium chromate provides reliable results of chloride (4500- $\mathrm{Cl}^{-}$.B of Standard Methods). Nitrate was analyzed by HACH Portable Spectrophotometer (DR 2800) by Cadmium Reduction Method (8039) adapted from Standard Methods at a wavelength of $450 \mathrm{~nm}$ [48]. Total Phosphorus was analyzed by HACH Portable Spectrophotometer (DR2800) by Molybdovanadate Method (10127) with Acid Persulfate digestion adapted from Standard Methods at a wavelength of $420 \mathrm{~nm}$ [45]. Sulphate was analyzed by $\mathrm{HACH}$ Portable Spectrophotometer (DR 2800) by SulfaVer 4 Method (8051) adapted from Standard Methods at a wavelength of $520 \mathrm{~nm}$ [48]. Heavy metals like Iron, Lead, Chromium, Cadmium, Copper, Zinc, Nickel and Arsenic were determined using ELICO double beam SL 210 UV-VIS Spectrophotometer [46].

\section{RESULTS AND DISCUSSION}

Leachate samples of MSW landfill site of ludhiana were collected and analyzed for various physico-chemical parameters to estimate its pollution potential. It has been found that leachate samples contain high concentration of organic and inorganic constituents beyond the permissible limits. While, heavy metals concentration was in trace amount as the waste is domestic in nature. The data presented in this study indicated that with the passage of time and with seasonal variations particularly during rainy season values of various parameters increased, reason being with time the solid waste material degraded and the waste constituents percolated down along with rainwater. Thus, the age and seasonal variations has a significant effect on leachate composition. The results of leachate analyzed for various physico-chemical characteristics and also standards for the discharge of treated leachates on Inland surface water, Public sewers and Land disposal were shown in Table 4.

\subsection{Color and Odour}

The color of leachate samples were orange brown or dark brown. Associated with the leachate is a malodorous smell, due mainly to the presence of organic acids, which come from the high concentration of organic matter when decomposed. The high concentration of colour in landfill leachate is due to the presence of high organic substances [47]. In general, leachate produced by an old landfill with low biodegradability is classified as stabilized leachate. Stabilized leachate contains high levels of organic substances such as humic and fluvic compounds, which can be indicated by leachate colour [48]. Humic substances are natural organic matter made up of complex structures of polymerized organic acids, carboxylic acids and carbohydrates [49].

\section{$3.2 \mathrm{pH}$}

$\mathrm{pH}$ values of leachate samples of the landfill site were 9.8, 9.10 and 10.3 during winter, summer and rainy season, respectively. The results are consistent with those published by previous authors $[50,51,52,53]$. Higher $\mathrm{pH}$ values of 8.39.10 were recorded from the stabilized leachate of semiaerobic landfill [48]. The $\mathrm{pH}$ varied according to the age of landfills [54]. Generally, the $\mathrm{pH}$ of a stabilized leachate is higher than that of a young leachate [55]. Leachate is generally found to have $\mathrm{pH}$ between 4.5 and 9 [56]. The $\mathrm{pH}$ of young leachate is less than 6.5 while old landfill leachate has $\mathrm{pH}$ higher than 7.5 [57,58]. Stabilized leachate shows fairly constant $\mathrm{pH}$ with little variations and it may range between 7.5 and 9. Chian and DeWalle reported that the $\mathrm{pH}$ of leachate increased with time due to the decrease of the concentration of the partially ionized free volatile fatty acids [35]. The increase in $\mathrm{pH}$ suggested that a steady state has been reached between acid producing processes (e.g., cellulose and lignin degradation) and acid consuming processes (e.g., methane formation) at the landfill [59].

\subsection{TS, SS and TDS}

TS and SS values of leachate samples of the landfill site were $7695 \mathrm{mg} / \mathrm{l}, 7896 \mathrm{mg} / \mathrm{l}, 8198 \mathrm{mg} / \mathrm{l}$ and $1132 \mathrm{mg} / \mathrm{l}, 1213 \mathrm{mg} / \mathrm{l}$ and $1335 \mathrm{mg} / \mathrm{l}$ during winter, summer and rainy season, respectively. Typical SS values of 200-2000 and 100-400 mg/l were recorded for the new (less than two years) and mature landfills (more than 10 years), respectively [10]. TDS values of leachate samples of the landfill site were $6563 \mathrm{mg} / \mathrm{l}, 6683$ $\mathrm{mg} / \mathrm{l}$ and $6863 \mathrm{mg} / \mathrm{l}$, respectively. TDS comprises mainly of inorganic salts and dissolved organics. TDS is one of the parameters taken into consideration for licensing discharge of landfill leachate in many countries such as the UK [60].

\subsection{Turbidity}

Turbidity values of leachate samples of the landfill site were 79 NTU, 85 NTU and 93 NTU during winter, summer and rainy season, respectively. The turbidity values in the present 
study are consistent with those in previous studies [47, 61, 62, 63].

\subsection{Hardness}

Hardness values of leachate samples of the landfill site were $638 \mathrm{mg} / \mathrm{l}, 728 \mathrm{mg} / \mathrm{l}$ and $823 \mathrm{mg} / \mathrm{l}$ during winter, summer and rainy season, respectively. The measured hardness values were considerably higher than the standard limit. The hardness values in the present study are consistent with those in previous studies $[61,62,63]$.

\section{6 $\mathrm{BOD}_{5}$}

BOD is the measure of biodegradable organic mass of leachate and that indicates the maturity of the landfill which typically decreases with time [64]. In this study, the BOD values for leachate at landfill site were $495 \mathrm{mg} / 1,512 \mathrm{mg} / \mathrm{l}$ and $596 \mathrm{mg} / \mathrm{l}$ during winter, summer and rainy season, respectively. The measured BOD values were considerably higher than the standard limit. The BOD values recorded for the leachate samples were above the permissible standard limit. This may be due to the reason that with time the solid waste material gets degraded and the waste constituents percolate down along with rainwater thus polluting groundwater nearby to MSW landfill site. BOD value varies according to age of landfills. For new landfills, BOD values were 2000-30000 mg/l; for mature landfills, BOD value varies from $100-200 \mathrm{mg} / \mathrm{l}$ [10]. Greater BOD values were reported by previous researchers $[47,50,65,66]$.

\subsection{COD}

COD represents the amount of oxygen required to completely oxidize the organic waste constituents chemically to inorganic end products. The COD values for leachate samples of the landfill site were $2535 \mathrm{mg} / \mathrm{l}, 2612 \mathrm{mg} / \mathrm{l}$ and $2935 \mathrm{mg} / \mathrm{l}$ during winter, summer and rainy season, respectively. The measured COD values were considerably higher than the standard limit. The COD values recorded for the leachate samples were above the permissible standard limit. This may be due to the reason that with time the solid waste material gets degraded and the waste constituents percolate down along with rainwater thus polluting groundwater nearby to MSW landfill site. Greater COD values were recorded by other studies [51, 61, 48, 63].

\section{8 $\mathrm{BOD}_{5} / \mathrm{COD}$ Ratio}

Organics in leachate are characterized by different levels of biodegradability. In this study, the $\mathrm{BOD}_{5} / \mathrm{COD}$ ratios for the collected leachate samples of the landfill site were $0.19,0.19$ and 0.20 during winter, summer and rainy season, respectively. The $\mathrm{BOD}_{5} / \mathrm{COD}$ ratio is consistent with those recorded by other researchers [47,51]. Generally, the $\mathrm{BOD}_{5} / \mathrm{COD}$ ratio describes the degree of biodegradation and gives information on the age of a landfill. The low $\mathrm{BOD}_{5} / \mathrm{COD}$ ratio shows the high concentration of non- biodegradable organic compounds and thus the difficulty to be biologically degraded [65].

\subsection{Chlorides}

The chloride values of leachate samples of the landfill site were $1836 \mathrm{mg} / \mathrm{l}, 1955 \mathrm{mg} / \mathrm{l}$ and $2336 \mathrm{mg} / \mathrm{l}$ during winter, summer and rainy season, respectively. The measured chloride values were considerably higher than the standard limit. Higher ranges of 490-1190, 360-4900 and 580-10100 mg/l were previously recorded by other researchers $[50,54,66]$. For new and mature landfills, the chloride values are 500 and 100$400 \mathrm{mg} / \mathrm{l}$, respectively [10]. According to Deng and Englehardt (2007), the concentration of chlorides may range between $200-3000 \mathrm{mg} / \mathrm{l}$ for a 1-2 year old landfill and the concentration decreases to 100-400 for a landfill greater than 5-10 years old [67].

\subsection{Nitrate}

The nitrate values for leachate at landfilling site were 18.6 $\mathrm{mg} / \mathrm{l}, 19.2 \mathrm{mg} / \mathrm{l}$ and $20.3 \mathrm{mg} / \mathrm{l}$ during winter, summer and rainy season, respectively. The measured nitrate values were considerably higher than the standard limit. Microbial decomposition of organic carbon influences on many processes of the nitrogen cycle. With time, nitrogen concentration decreased due to microbial utilization of nitrate compounds and denitrifying as ammonia gas [68]. Nitrates are the primary contaminant that leaches into groundwater. The United States Environmental Protection Agency (USEPA) has set a maximum contaminant level of $10 \mathrm{mg} / \mathrm{l}$ for nitrate in public water supplies [69].

\subsection{Total Phosphorus}

Total phosphorus values for leachate at landfill site were 83.5 $\mathrm{mg} / 1,88.3 \mathrm{mg} / \mathrm{l}$ and $90.6 \mathrm{mg} / \mathrm{l}$ during winter, summer and rainy season, respectively. The measured total phosphorus values were considerably higher than the standard limit. Phosphorus is one of the key elements necessary for growth of plants and animals and is a backbone of the Kreb's Cycle and Deoxyribonucleic acid (DNA). Phosphorus transported from agricultural lands to surface water can promote eutrophication, which is one of the leading water quality issues in lakes and reservoirs. Current recommendations of USEPA, total $\mathrm{P}$ should not exceed $0.05 \mathrm{mg} / \mathrm{l}$ in a stream at a point where it enters a lake or reservoir and $0.1 \mathrm{mg} / \mathrm{l}$ in streams that do not discharge directly into lakes or reservoirs [69].

\subsection{Sulphate}

Sulphate values for leachate at landfill site were $48.7 \mathrm{mg} / \mathrm{l}$, $65.1 \mathrm{mg} / \mathrm{l}$ and $53.8 \mathrm{mg} / \mathrm{l}$ during winter, summer and rainy season, respectively. Sulphate values of $98-374$ and 22-650 $\mathrm{mg} / \mathrm{l}$ were previously recorded by other researchers [54]. Typical sulphate values of 300 and $20-50 \mathrm{mg} / \mathrm{l}$ were recorded for new (less than two years) and mature (more than 10 years) 
landfills, respectively [10]. However, the measured sulphate values were exceeded the permissible level $(0.50 \mathrm{mg} / \mathrm{l})$. The sulphate content of leachate mainly depends on the decomposition of organic matter present in the solid wastes. It is expected to decrease with refuse age. This decrease is caused by the reduction of sulphate to sulphide coincident with the initiation of anaerobic conditions in the landfill [70]. Thus, the sulphate concentration in leachate can also be used as an indicator of waste stabilization within landfill.

\subsection{Heavy Metals}

Heavy metals viz Iron, Lead, Chromium, Cadmium, Copper, Zinc, Nickel and Arsenic values for leachate at landfill site were in trace amount as the waste is domestic in nature.

In general, the concentration of heavy metals in landfill leachate is fairly low [56]. Concentration of heavy metals in a landfill is generally higher at earlier stages because of higher metal solubility as a result of low $\mathrm{pH}$ caused by production of organic acids [54]. As a result of decreased $\mathrm{pH}$ at later stages, a decrease in metal solubility occurs resulting in rapid decrease in concentration of heavy metals [33].

Table -4. Physico-chemical characteristics of the leachate samples

\begin{tabular}{|c|c|c|c|c|c|c|}
\hline \multirow[t]{2}{*}{ Parameters* } & \multicolumn{3}{|c|}{ Jamalpur landfill site } & \multicolumn{3}{|c|}{ Standards (Mode of Disposal )** } \\
\hline & $\begin{array}{c}\text { Jan, } 2012 \\
\text { (Winter Season) }\end{array}$ & $\begin{array}{c}\text { May, } 2012 \\
\text { (Summer Season) }\end{array}$ & $\begin{array}{c}\text { July, } 2012 \\
\text { (Rainy Season) }\end{array}$ & $\begin{array}{c}\text { Inland } \\
\text { surface } \\
\text { water }\end{array}$ & $\begin{array}{l}\text { Public } \\
\text { sewers }\end{array}$ & Land disposal \\
\hline $\mathrm{pH}$ & 9.8 & 9.10 & 10.3 & 5.5 to 9.0 & 5.5 to 9.0 & 5.5 to 9.0 \\
\hline $\mathrm{TS}$ & 7695 & 7896 & 8198 & - & - & - \\
\hline SS & 1132 & 1213 & 1335 & 100 & 600 & 200 \\
\hline TDS & 6563 & 6683 & 6863 & 2100 & 2100 & 2100 \\
\hline Turbidity (NTU) & 79 & 85 & 93 & 5 & 10 & 10 \\
\hline Hardness & 638 & 728 & 823 & 300 & - & - \\
\hline $\begin{array}{l}\text { BOD (5 days at } \\
\left.25^{\circ} \mathrm{C}\right) \text { max. }\end{array}$ & 495 & 512 & 596 & 30 & 350 & 100 \\
\hline COD & 2535 & 2612 & 2935 & 250 & - & - \\
\hline $\mathrm{BOD}_{5} / \mathrm{COD}$ & 0.19 & 0.19 & 0.20 & - & - & - \\
\hline Chloride & 1836 & 1955 & 2336 & 1000 & 1000 & 600 \\
\hline Nitrate & 18.6 & 19.2 & 20.3 & - & - & - \\
\hline Total Phosphorus & 83.5 & 88.3 & 90.6 & - & - & - \\
\hline Sulphate & 65.1 & 66.9 & 68.3 & - & - & - \\
\hline
\end{tabular}

* All values in mg/l except for $\mathrm{pH}$ and turbidity.

** Municipal Solid Wastes (Management and Handling) Rules, 2000

\section{CONCLUSIONS}

- Landfill site of Ludhiana City is non-engineered low lying open dump. It has neither any bottom liner nor any leachate collection and treatment system. Therefore, all the leachate generated finds its paths into the surrounding environment.

- Leachate samples of landfill site were collected and analyzed for various physico-chemical parameters to estimate its pollution potential. It has been concluded that leachate samples contain high concentration of organic and inorganic constituents beyond the permissible limits. While, heavy metals concentration was in trace amount as the waste is domestic in nature. The measured leachate samples would need an appropriate treatment strategy to reduce the pollutants to a satisfactory level prior to discharge into receiving system.

- The data presented in this study indicated that with the passage of time and with seasonal variations particularly during rainy season values of various parameters increased, reason being with time the solid waste material degraded and the waste constituents percolated down along with rainwater. Thus, the age and seasonal variations has a significant effect on leachate composition. 


\section{REFERENCES}

[1] M. Sharholy, K. Ahmad, R. Vaishya, R. Gupta, Municipal solid waste characteristics and management in Allahabad, India, Journal of Waste Management, 27 (4), 2007, 490-496.

[2] A.Idris, B.Inane, M.N.Hassan, Overview of waste disposal and landfills/dumps in Asian countries, Material Cycles and Waste Management, 16, 2004, 104-110.

[3] MoEF, Municipal solid wastes (management and handling) rules, Ministry of Environment and Forests, Government of India, New Delhi (2000).

[4] A. Kansal, Solid waste management strategies for India, Indian Journal of Environmental Protection, 22(4), 2002, 444-448.

[5] TERI, Looking back to think ahead- Green India 2047, Tata Energy Research Institute, New Delhi, 1998, 346.

[6] Shaleen Singhal and Suneel Pandey, Solid waste management in India: status and future directions, TERI Information Monitor on Environmental Science, 6(1), 2001, 1-4.

[7] MoUD, Manual on municipal solid waste management, The Expert Committee constituted by Ministry of Urban Development, Government of India, 2000.

[8] N.Ahsan, Solid waste management plan for Indian megacities, Indian Journal of Environmental Protection, 19(2), 1999, 90-95

[9] C.Visvanathan and J. Trankler, Municipal solid waste management in Asia: A comparative analysis, Workshop on Sustainable Landfill Management, 3-5 December, Chennai, India, 2003, 3-15.

[10] G.Tchobanoglous, H. Theisen and S. A. Vigil, Integrated solid waste management engineering principles and management issues ( $1^{\text {st }}$ ed.) (New York: McGraw-Hill, 1993).

[11] S.Sharma, K.W.Shah, Generation and disposal of solid waste in Hoshangabad. In: Book of Proceedings of the Second International Congress of Chemistry and Environment, Indore, India, 2005. 749-751.

[12] CPCB, Management of municipal solid waste, Ministry of Environment and Forests, New Delhi, India, 2004.

[13] A.V.Shekdar, Municipal solid waste management - the Indian experience, Journal IAEM, 27, 1999, 100-108

[14] S.Mor, K.Ravindra, A.D.Visscher, R.P.Dahiya, A. Chandra, Municipal solid waste characterization and its assessment for potential methane generation: a case study, Journal of Science of the Total Environment, 371(1), 2006, 1-10.

[15] D.V. Raje, P.D.Wakhare, A.W. Despande, A.D. Bhide, An approach to assess level of satisfaction of the residents in relation to SWM system, Journal of Waste Management and Research, 19, 2001, 12-19.

[16] A.Khajuria, Y.Yamamoto and T. Mori-oka, Solid waste management in Asian countries: problems and issues. Proc. of $4^{\text {th }}$ International Conference on Waste management and environment, June, 2-4, 109, 2008, 643-653.

[17] S.Gupta, N.Choudhary and B.J.Alappat, Bioreactor Landfill for MSW Disposal in Delhi, Proceedings of the International Conference on Sustainable Solid Waste Management, Chennai, India, 2007, 474-481.

[18] S.Rathi, Alternative approaches for better municipal solid waste management in Mumbai, India, Journal of Waste Management, 26 (10), 2006, 1192-1200.

[19] M. Sharholy, K.Ahmad, G.Mahmood, R.C.Trivedi, Analysis of municipal solid waste management systems in Delhi - a review. In: Book of Proceedings for the second International Congress of Chemistry and Environment, Indore, India, 2005, 773-777.

[20] M.R.Ray, S.Roychoudhury, G.Mukherjee, S.Roy, T.Lahiri, Respiratory and general health impairments of workers employed in a municipal solid waste disposal at open landfill site in Delhi. International Journal of Hygiene and Environmental Health, 108 (4), 2005.255262.

[21] M.K.Jha, O.A.K.Sondhi, M.Pansare, Solid waste management- a case study, Indian Journal of Environmental Protection, 23 (10), 2003, 1153-1160.

[22] S.K. Singh and R.S. Singh, A study on municipal solid waste management practices in Dhanbad -Jharia coalifield, Indian Journal of Environmental Protection, 18(11), 1998, 850-852.

[23] T.H. Christensen and P. Kjeldsen, Basic biochemical processes in landfills, Chapter 2.1 in Sanitary Landfilling: Process, Technology and Environmental Impact, Christensen, T.H., Cossu, R and Stegmann, R., Eds., Academic Press, London, UK, 1989, 29.

[24] S. Renou, J.G. Givaudan, S. Poulain, F. Dirassouyan, and P. Moulin, Landfill leachate treatment: Review and opportunity, Journal of Hazardous Materials, 150, 2008, 468-493.

[25] A.H. Robinson, Landfill leachate treatment, Journal of Membrane Technology, 2005, 6-12.

[26] T.H.Christensen, R. Stegmann Cossu and R. Stegmann, Landfill Leachate: An introduction, In: Landfilling of waste: Leachate, Elsevier, 1992, 3-14.

[27] C.D. Iaconi, R. Ramadori, A. Lopez, Combined biological and chemical degradation for treating a mature municipal landfill leachate, Biochemical Engineering Journal, 31, 2006, 118-124.

[28] S. Park, K.S. Choi, K.S. Joe, H.S. Kim, Variations of landfill leachate`s properties in conjunction with the treatment process. Journal of Environmental Technology, 22, 2001, 639-645.

[29] A.Kouzeli-Katsari, A. Bodogianni and D.Chritoulas, Prediction of leachate quality from sanitary landfills, Journal of Environmental Division, ASCE, 125 (EE10), 1999, 950-957.

[30] K.Westlake, Landfill waste pollution and control (Albion publishing limited, England, 1995). 
[31] R.Canziani and R.Cossu, Landfill hydrology and leachate production, sanitary landfilling: Process, Technology and Environmental Impact: Academic Press, 1989.

[32] U. Welander, Characterisation and treatment of municipal landfill leachates, Thesis at Department of Biotechnology, Lund University, 1998.

[33] J. Harmsen, Identification of organic compounds in leachate from a waste tip, Journal of Water Research, 17(6), 1983, 699-705.

[34] H.D.Robinson, J.R. Gronow, A review of landfill leachate composition in the UK, Proc. Sardinia 1, CISA: 1993, 821-831.

[35] E.S.K. Chian and E.B. Dewalle, Sanitary landfill leachate and their treatment, Journal of Environ-mental Engineering Division, ASCE, 108(EE2), 1976, 411.

[36] C.Granet, N. Courant, C. Millot, C. Rousseau and A. Navarro, Diagnostic detraitabilité des lixiviats : définition d'une méthodologie, L'Eau et l'Industrie, Janvier, 1986.

[37] A.Amokrane, C.Comel and J. Veron, Landfill leachates pretreatment by coagulation-flocculation, Journal of Water Research, 31, 1997, 2775-2782.

[38] E.A. McBean, F.A.Rovers, G.J. Farquhar, Solid waste landfill engineering and design (Prentice Hall PTR, New Jersey, USA, 1995).

[39] F.Wang, D.W.Smith, M.G. El-Din, Application of advanced oxidation methods for landfill leachate treatment, Journal of Environmental Engineering and Science, 2, 2003. 413-427.

[40] U.Welander, T.Henryson, T.Welander, Nitrification of landfill leachate using suspended-carrier biofilm technology, Water Research, 31, 1997, 2351-2355.

[41] E. Diamadopoulos, Characterization and treatment of recirculation-stabilized leachate, Water Research, 28(22), 1994, 2439-2445.

[42] www.census2011.co.in/census/district/594 -ludh.html

[43] Vision 2021, Ludhiana City Development Plan, Municipal Corporation, Ludhiana initiative under Jawaharlal Nehru National Urban Renewal Mission.

[44] APHA, Standard methods for the examination of water and wastewater. $21^{\text {st }}$ edition, American Public Health Association, American Water Works Association, Water Environment Federation Publication, Washington, DC., 2005.

[45] Manual of HACH Portable Spectro-photometer (DR 2800)

[46] Manual of ELICO double beam SL 210 UV-VIS Spectrophotometer

[47] H.A. Aziz, S. Alias, M. N. Adlan, F. A. H. Asaari and M. S. M. Zahari, Colour removal from landfill leachate by coagulation and flocculation process, Bioresource Technology, 98, 2007, 218-220.

[48] M. J. K. Bashir, H. A. Aziz, M. S. Yusoff, and M. N. Adlan, Application of response surface methodology (RSM) for optimization of ammonical nitrogen removal from semi-aerobic landfill leachate using ion exchange resin. Desalination, 254, 2010, 154-161.

[49] B. Langlais, D.A. Reckhow and D.R. Brink, Ozone in water treatment: application and engineering (Chelsea, MI: Lewis Publishers Inc.,1991).

[50] N.A. Zainol, Hamidi Abdul Aziz and Mohd Suffian Yusoff, Characterization of Leachate from Kuala Sepetang and KulimLandfills: A Comparative Study, School of Civil Engineering, Universiti Sains Malaysia, Energy and Environment Research, 2(2), 2012, 45-52.

[51] S. Q. Aziz, H. A. Aziz, M. S. Yusoff and M.J.K. Bashir, Leachate characterization in semi-aerobic and anaerobic sanitary landfills: A comparative study, Journal of Environmental Management, 91, 2010, 2608-2614.

[52] P. Palaniandy, M.N. Adlan, H.A. Aziz, and M.F. Murshed, Application of dissolved air flotation (DAF) in semi-aerobic leachate treatment, Chemical Engineering Journal, 157, 2010, 316-322.

[53] Q. Zhong, D.Li, Y.Tao, X. Wang, X.He, J. Zhang and L. Wang, Nitrogen removal of landfill leachate via ex situ nitrification and sequential in situ denitrification. Waste Management, 29, 2009, 1347-1353.

[54] D. Kulikowska and E. Klimiuk, The effect of landfill age on municipal leachate composition. Bioresource Technology, 99, 2008, 5981-5985.

[55] T.G.Poznyak, L.Bautista, I.R. Chairez, I.Cordova and E. Rios, Decomposition of toxic pollutants in landfill leachate by ozone after coagulation treatment. Journal of Hazardous Materials, 152, 1108-1114.

[56] T.H.Christensen, P. Kjeldsen, and P. Kjeldsen, Biogeochemistry of landfill leachate plumes, Applied Geochemistry, 16(7-8), 2001, 659-718.

[57] A.A. Abbas, G. ingsong, L. Z. ing, P. Y. Ya and W. S. Al-Rekabi, Review on landfill leachate treatments, Journal of Applied Sciences Research, 5(5), 2009, 534-545,.

[58] J. Bohdziewicz and A. Kwarciak, The application of hybrid system UASB reactor-RO in landfill leachate treatment, Desalination, 222(1-3), 2008, 128-134.

[59] L.M. Chu, K.C. Cheung and M.H. Wong, Variations in the chemical properties of landfill leachate, Journal of Environmental management, 18(1), 1994, 105-117.

[60] L. Koshy, T. Jones and K. BeruBe, Bioreactivity of municipal solid waste landfill leachates-Hormesis and DNA damage, Water Research, 42 (8-9), 2008, 2177 2183.

[61] H. A. Aziz, Z. Daud, M. N. Adlan, and Y. T.Hung, The use of polyaluminium chloride for removing colour, COD and ammonia from semi aerobic leachate. International Journal of Environmental Engineering, 1, 2009, 20-35.

[62] H. A. Aziz, M. S. Yusoff, M. N. Adlan, N. H. Adnan, and S. Alias, Physico-chemical removal of iron from semi-aerobic landfill leachate by limestone filter, Waste Management, 24(4), 2004, 353-358. 
[63] A. A. Tatsi, A. I. Zouboulis K. A. Matis, and P. Samaras, Coagulation-flocculation pretreatment of sanitary landfill leachates, Chemosphere, 53(7), 2003, 737-744,.

[64] S.R.Qasim and W.Chiang, Sanitary Landfill Leachate. Generation Control and Treatment (Lancaster, PA : Tecnomic Publication, 1994).

[65] X. Ntampou, A.I. Zouboulis and P. Samaras, Appropriate combination of physicochemical methods for the efficient treatment of landfill leachates, Chemosphere, 62, 2006, 722-730.

[66] A. A. Tatsi and A. I. Zouboulis, A field investigation of the quantity and quality of leachate from a municipal solid waste landfill in a Mediterranean climate, Thessaloniki, Greece, Advances in Environmental Research, 6(3), 207-219, 2002.

[67] Y. Deng and J. D. Englehardt, Treatment of landfill leachate by the Fenton process, Water Research, 40(20), 2006, 3683-3694,.

[68] D. Wu, X. Quan, Y. Zhang and Y. Zhao, Long-term operation of a compost-based biofilter for biological removal of n-butyl acetate, p-xylene and ammonia gas from an air stream. Bioche. Engi. J. 32(2), 2006, 84-92.

[69] U.S. Environmental Protection Agency (USEPA), Non point Source Control Branch (4503T) 1200 Pennsylvania Avenue, NW Washington, DC 20460, 2005.

[70] D. Shivakumar, B.S. Thandaveswara and K.D. Chandrasekaran, Solid waste leachate quality and its effects on soil properties, Pollution Research, 23(1), 2004, 69-81. 